Proceedings

\title{
Insecticidal Potential of Indigenous Flora of Soon Valley against Asian Citrus Psyllid Diaphorina citri Kuwayama and Cotton Aphid Aphis gossypii Glover ${ }^{+}$
}

\author{
Muhammad Bilal Tayyab ${ }^{1,}$ Muhammad Zeeshan Majeed ${ }^{1, *}$ and Muhammad Asam Riaz ${ }^{1}$ \\ 1 Department of Entomology, College of Agriculture, University of Sargodha, Sargodha 40100, Pakistan; \\ hmbt222@gmail.com (MBT); zeeshan.majeed@uos.edu.pk (MZM); asam.riaz@uos.edu.pk (MAR) \\ * Correspondence: zeeshan.majeed@uos.edu.pk \\ + Presented at the 1st International Electronic Conference on Entomology (IECE 2021), 1-15 July 2021; Availa- \\ ble online: https://iece.sciforum.net/.
}

\begin{abstract}
Diaphorina citri Kuwayama (Psyllidae: Hemiptera) and Aphis gossypii Glover (Aphididae; Hemiptera) are destructive sap-feeding pests of citrus and cotton, respectively. This study assessed the toxicity potential of indigenous flora of Soon valley and surrounding salt range (Punjab, Pakistan) against D. citri and A. gossypii. Among acetone extracts of 40 plant species, the extracts of Mentha longifolia (L.) Huds., Melilotus officinalis (L.) Pall., Nerium indicum Mill., Datura alba L. and Salvia officinalis L. showed highest psyllid mortality (i.e. 93, 91, 89, 88 and $81 \%$, respectively). Bioassay with most effective extracts further revealed that the most toxic extracts were S. officinalis, N. indicum and M. longifolia with LC 50 values of 18.59, 20.27 and 20.73\%, respectively. Similar trend of toxicity was observed in case of their $\mathrm{LT}_{50}$ values. These results suggest the putative effectiveness and further biochemical characterization of these plant extracts for the management of D. citri and A. gossypii and other sap-feeding insect pests.
\end{abstract}

Citation: Tayyab, M.B.; Majeed, M.Z.; Riaz, M.A. Insecticidal Potential of Indigenous Flora of Soon Valley against Asian Citrus Psyllid Diaphorina citri Kuwayama and Cotton Aphid Aphis gossypii Glover, in Proceedings of the 1st International Electronic Conference on Entomology, 1-15 July 2021, MDPI: Basel, Switzerland, doi:10.3390/IECE-10367

Published: 30 June 2021

Publisher's Note: MDPI stays neutral with regard to jurisdictional claims in published maps and institutional affiliations.

Copyright: (c) 2021 by the authors. Submitted for possible open access publication under the terms and conditions of the Creative Commons Attribution (CC BY) license (http://creativecommons.org/licenses /by/4.0/).
Keywords: Botanical pesticides; Phytoextracts; Sap-feeding pests; Diaphorina citri; Aphis gossypii; Toxicity evaluation

\section{Introduction}

Insect pests adversely affect the world food production. Among these, sap-feeding insect pests have been a serious threat to agricultural and horticultural crops all over the world including Pakistan. Although Pakistan ranks among the top citrus and cotton producing and exporting countries of the world, per unit area production of both these crops is far-behind than other top countries. Occurrence of insect pests and diseases are the major limiting factors for this decreased citrus and cotton production in Pakistan $[1,2]$.

Asian citrus psyllid (ACP) Diaphorina citri Kuwayama (Psyllidae: Hemiptera) and cotton aphid Aphis gossypii Glover (Aphididae; Hemiptera) are the most destructive pests of citrus and cotton crops, respectively. For the control of both these pests, citrus and cotton growers rely exclusively on extensive applications of highly persistent synthetic insecticides which are also causing many environmental and health issues [3], insect pests resistance $[4,5]$, eradication of non-target fauna including predators and parasitoids $[6,7]$ and human health hazards [8].

This situation demands for searching novel biorational pest management strategies which would be more environment-friendly and safer than synthetic chemical insecticides such as plant-based pesticides which appear as promising alternative control measures [9]. This study was conducted to explore the indigenous flora (including herbs, shrubs and trees) of Soon valley and surrounding Salt Range (Khushab, Punjab, Pakistan) for their toxicity potential against $D$. citri and A. gossypii.

\section{Methods}




\subsection{Collection and Extraction of Plant Materials}

Samples of indigenous flora (including trees, shrubs and herbs) were collected from six selected sites (Angah, Dape Shareef, Kenhatti Garden, Khabeki, Khoora and Uchhali) of Soon valley and surrounding Salt Range of district Khushab (Punjab, Pakistan) as detailed in Table 1. Collected plants were identified up to species level and were extracted by the Soxhlet extractor (DH.WHM-12393, Daihan Scientific, South Korea) using pure acetone as extraction solvent using 1:10 plant material: acetone ratio. Pure botanical extract obtained from each plant sample was stored in $50 \mathrm{~mL}$ hermetic dark glass vial and was refrigerated until its downstream utilization in the toxicity bioassays.

Table 1. Geographical coordinates of selected flora collection sites in Soon Valley and surrounding Salt Range of Pakistan.

\begin{tabular}{llllll}
\hline Sr. No. & Localities & Latitude N & Longitude E & Elevation $(\mathrm{m})$ \\
\hline $\mathrm{T}$ & 1. & Angah & $32.35^{\circ} \mathrm{N}$ & $72.05^{\circ} \mathrm{E}$ & 821 \\
$\mathrm{~h}$ & 2. & Dape Sharif & $32.30^{\circ} \mathrm{N}$ & $72.04^{\circ} \mathrm{E}$ & 890 \\
$\mathrm{e}$ & 3. & Kenhatti Garden & $32.40^{\circ} \mathrm{N}$ & $72.14^{\circ} \mathrm{E}$ & 783 \\
$\mathrm{t}$ & 3. & & $32.35^{\circ} \mathrm{N}$ & $72.12^{\circ} \mathrm{E}$ & 774 \\
$\mathrm{e}$ & 4. & Khabeki & $32.23^{\circ} \mathrm{N}$ & $72.11^{\circ} \mathrm{E}$ & 866 \\
$\mathrm{x}$ & 5. & Khoora & $32.56^{\circ} \mathrm{N}$ & $72.02^{\circ} \mathrm{E}$ & 794 \\
$\mathrm{t}$ & 5. & Uchhali & & & \\
\hline
\end{tabular}

\subsection{Insect Culture}

Active adults of ACP (D. citri) were collected from the citrus field (Citrus reticulata Blanco cv. kinnow mandarin) by means of manual aspirator and were reared on potted citrus jasmine (Murraya paniculata (L.) Jack) plants. Aphid (A. gossypii) colonies were collected cotton field and were reared on potted cotton (Gossypium hirsutum L.) plants. Insects were reared at $27 \pm 3^{\circ} \mathrm{C}$ temperature, $60 \pm 5 \%$ relative humidity and $16 \mathrm{~h} \mathrm{~L}: 8 \mathrm{~h} \mathrm{D}$ photoperiod.

\subsection{Insecticidal Bioassays}

First bioassay was conducted in order to screen out the most effective botanical extracts against ACP (C. citri) individuals using twig-dip bioassay method. Later on, based on the results of this preliminary toxicity experiment, we conducted our 2nd series of toxicity bioassays with detailed experimental parameters using laboratory reared aphid (A. gossypii) individuals using leaf-dip bioassay method. After exposure of 5 to 10 freshly molted lab reared insect individuals to different concentrations, they were incubated in an environmental chamber under controlled conditions i.e. at $27 \pm 2^{\circ} \mathrm{C}$ and $60 \pm 5 \%$ relative humidity. Experimental design was completely randomized with three to five replicates maintained for each treatment. Data regarding the mortality of exposed insect individuals was recorded at $12,24,48$ and $72 \mathrm{~h}$ post-treatment.

\subsection{Statistical Analysis}

Statistical interpretation of data was performed using analytical software Statistix V. 8.1®. Apart from graphical presentation, percent mortality data were analyzed by factorial analysis of variance (ANOVA) taking botanical solutions, concentrations and time intervals as factors. Treatment means were further compared using HSD test at $95 \%$ 
probability level $(\mathrm{P}<0.05)$. Median lethal concentration $\left(\mathrm{LC}_{50}\right)$ and time $\left(\mathrm{LT}_{50}\right)$ values were calculated by probit analysis using IBM SPSS $®$ statistics regression software. Prior to statistical analysis, mortality data was corrected using Abbott's formula [10].

\section{Results}

Results of preliminary screening experiment performed with $10 \%$ extracts showed that some botanical extracts caused significant mortality of adult psyllid individuals ( $\mathrm{F}=$ 44.82; P $\leq 0.01$ ). The extracts of M. longifolia (93\%), followed by M. officinalis $(91 \%)$ and $N$. indicum (89\%), while the extracts of D. alba and S. officinalis showed 88 and $81 \%$ mortality, respectively. Whereas about $57 \%$ mortality was caused by R. smithi and remaining all botanicals caused less than 50\% psyllid mortality (data not shown).

Results of detailed toxicological bioassays carried out against $A$. gossypii revealed a differential response of aphid individuals against different plant extracts. There was a significant effect of all botanical extracts on aphid mortality $(\mathrm{F}=181.30 ; \mathrm{P} \leq 0.01)$. Overall, the highest average mortality (63\%) of aphid individuals was observed in case of S. officinalis, followed by D. viscosa, and O. ferruginea exhibiting 62 and $60 \%$ average aphid mortality, respectively, while M. longifolia and N. indicum both exhibited about 58\% aphid mortality for $40 \%$ concentrations (Figure 1).

Similar trend of toxicity was observed for median lethal concentration (LC50) and median lethal time (LT50) values were calculated for the botanical extracts. According to probit analysis, S. officinalis was the most effective at $48 \mathrm{~h}\left(\mathrm{LC}_{50}=18.59 \%\right)$, followed by the extract of $N$. indicum $\left(\mathrm{LC}_{50}=20.27 \%\right.$ ) and M. longifolia $\left(\mathrm{LC}_{50}=20.73 \%\right)$, while the extracts of S. officinalis, M. longifolia and N. indicum showed minimum LC 50 values (i.e. 9.24, 9.51 and $10.98 \%$, respectively) at $72 \mathrm{~h}$ (Table 2). Similar trend was found in case of median lethal time ( $\left.\mathrm{LT}_{50}\right)$ values. The $40 \%$ extracts of S. officinalis and O. ferruginea showed minimum $\mathrm{LT}_{50}$ values (i.e. 17.73 and $20.05 \%$, respectively) (Table 3). 

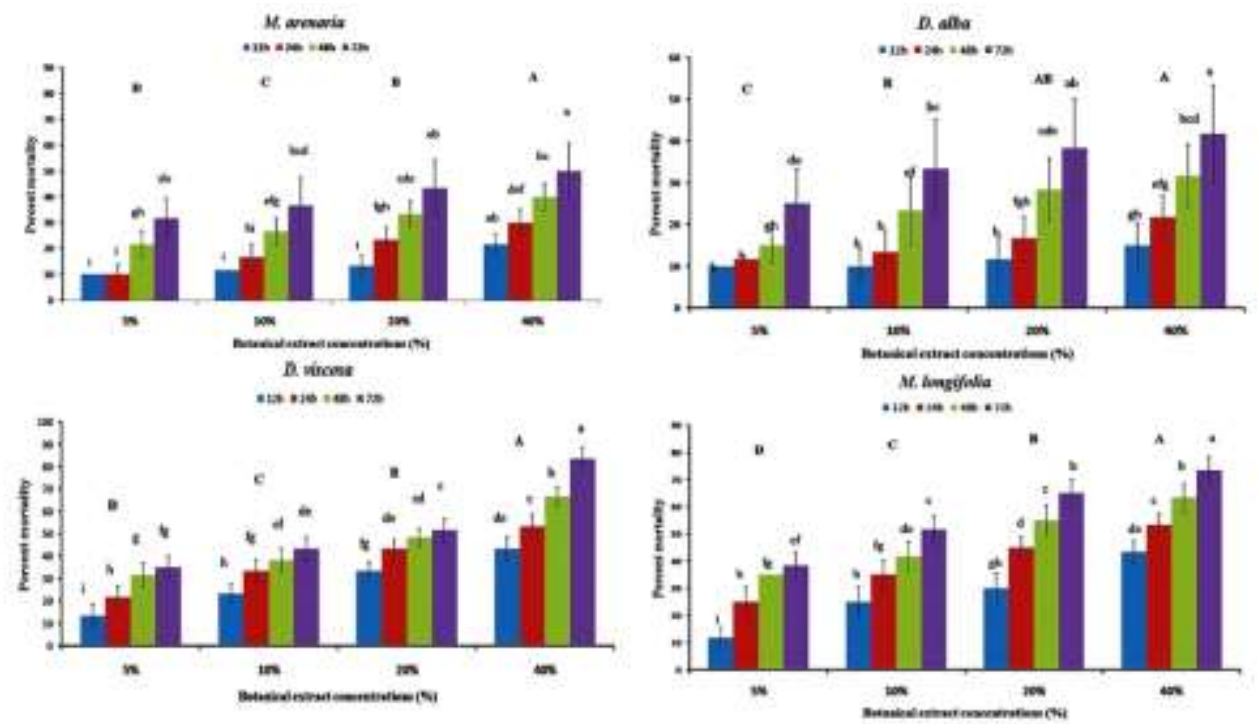

N hatican
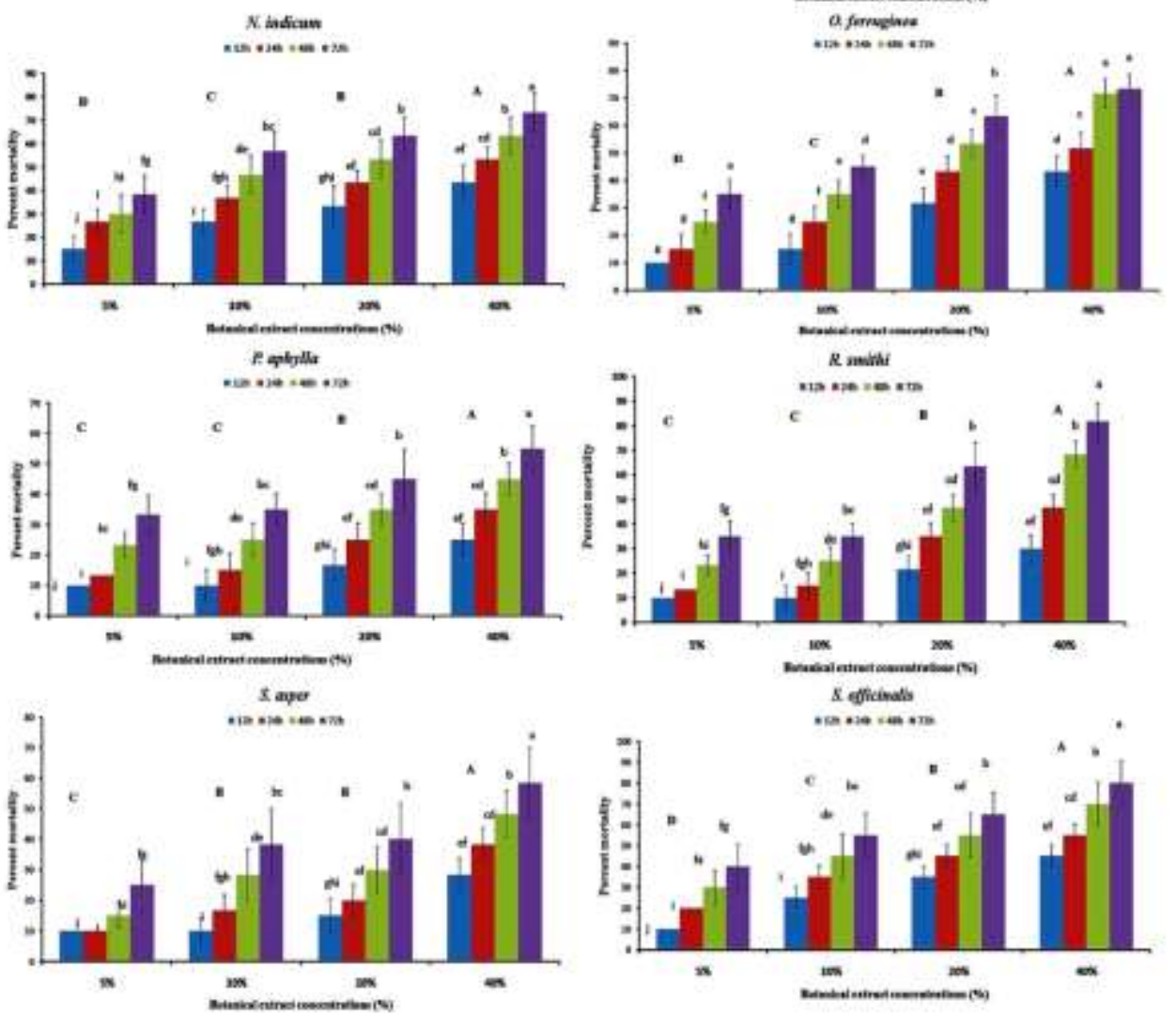

Figure 1. Percent mortality (mean $\pm \mathrm{SE} ; \mathrm{n}=10$ ) of cotton aphid (A. gossypii) individuals exposed to different concentrations of botanical extracts observed at different post-exposure time intervals. For each botanical extract, small alphabets indicate statistical difference among time intervals for each concentration, while capital alphabets are indicating the statistical difference among different concentrations (one-way factorial ANOVA; HSD at $\alpha=0.05$ ). 
Table 2. Median lethal concentration ( $\mathrm{LC}_{50}$ ) values of different acetone extracts of Soon valley flora bioassayed against freshly molted adults of cotton aphid (Aphis gossypii)

\begin{tabular}{|c|c|c|c|c|c|}
\hline Treatments & $\begin{array}{l}\text { Observation } \\
\text { time (h) }\end{array}$ & $\begin{array}{l}\mathrm{LC}_{50} \\
(\%)\end{array}$ & $\begin{array}{l}\text { Lower and Upper } 95 \% \\
\text { Fiducial Limits }(\%)\end{array}$ & $\begin{array}{l}X^{2}(D F= \\
10)^{*}\end{array}$ & P-value \\
\hline \multirow[t]{2}{*}{ Maerua arenaria $\mathrm{H}$ \& Thom. } & 48 & 63.76 & $50.29-110.45$ & 52.28 & $\leq 0.001$ \\
\hline & 72 & 58.80 & 46.71-104.04 & 47.09 & 0.001 \\
\hline \multirow[t]{2}{*}{ Mentha longifolia (L.) Huds. } & 48 & 20.27 & $-38.57-42.65$ & 31.59 & 0.06 \\
\hline & 72 & 10.98 & $-53.43-34.84$ & 42.51 & $\leq 0.001$ \\
\hline \multirow[t]{2}{*}{ Nerium indicum Mill. } & 48 & 20.73 & $-233.28-52.07$ & 76.59 & $\leq 0.001$ \\
\hline & 72 & 9.51 & $-192.30-43.54$ & 77.35 & $\leq 0.001$ \\
\hline \multirow[t]{2}{*}{ Rhamnus smithi Greene } & 48 & 25.63 & $-5.3-36.68$ & 53.36 & $\leq 0.001$ \\
\hline & 72 & 15.67 & $-21.99-29.56$ & 60.05 & $\leq 0.001$ \\
\hline \multirow[t]{2}{*}{ Datura alba $\mathrm{L}$. } & 48 & 66.67 & $\mathrm{NC}$ & 83.58 & $\leq 0.001$ \\
\hline & 72 & 72.40 & $\mathrm{NC}$ & 67.28 & $\leq 0.001$ \\
\hline \multirow[t]{2}{*}{ Periploca aphylla Decne. } & 48 & 54.17 & $40.16-91.96$ & 67.92 & $\leq 0.001$ \\
\hline & 72 & 50.03 & $38.06-75.57$ & 63.27 & $\leq 0.001$ \\
\hline \multirow[t]{2}{*}{ Sonchus asper (L.) Hill } & 48 & 41.13 & $\mathrm{NC}$ & 83.23 & $\leq 0.001$ \\
\hline & 72 & 30.11 & $\mathrm{NC}$ & 69.70 & $\leq 0.001$ \\
\hline \multirow[t]{2}{*}{ Salvia officinalis L. } & 48 & 18.59 & $-37.88-37.87$ & 48.74 & 0.001 \\
\hline & 72 & 9.24 & $-64.61-32.39$ & 52.07 & $\leq 0.001$ \\
\hline \multirow[t]{2}{*}{ Dodonaea viscosa (L.) Jacq. } & 48 & 22.51 & $-55.11-41.97$ & 17.49 & 0.012 \\
\hline & 72 & 27.61 & $19.66-32.07$ & 27.63 & 0.015 \\
\hline \multirow[t]{2}{*}{ Olea ferruginea Wall. ex Aitch. } & 48 & 21.50 & $-2.12-32.91$ & 46.10 & 0.001 \\
\hline & 72 & 14.62 & $-29.37-33.02$ & 45.71 & 0.001 \\
\hline
\end{tabular}


Table 3. Median lethal time (LT50) values of different acetone extracts of Soon valley flora bioassayed against freshly molted adults of cotton aphid (Aphis gossypii)

\begin{tabular}{|c|c|c|c|c|c|}
\hline Treatments & $\begin{array}{l}\text { Botanical } \\
\text { conc. }(\%)\end{array}$ & $\mathrm{LT}_{50}(\mathrm{~h})$ & $\begin{array}{l}\text { Lower and Upper } 95 \% \\
\text { Fiducial Limits (h) }\end{array}$ & $\begin{array}{l}X^{2}(\mathrm{DF}= \\
10)^{*}\end{array}$ & P-value \\
\hline \multirow[t]{2}{*}{ Maerua arenaria $\mathrm{H} \&$ Thom. } & 20 & 80.88 & $72.35-93.52$ & 35.85 & 0.02 \\
\hline & 40 & 70.16 & $58.43-93.37$ & 96.97 & $\leq 0.001$ \\
\hline \multirow[t]{2}{*}{ Mentha longifolia (L.) Huds. } & 20 & 41.29 & $37.63-45.06$ & 29.76 & 0.012 \\
\hline & 40 & 21.63 & $16.03-26.18$ & 25.33 & 0.028 \\
\hline \multirow[t]{2}{*}{ Nerium indicum Mill. } & 20 & 42.47 & $35.19-50.49$ & 58.94 & $\leq 0.001$ \\
\hline & 40 & 21.63 & $10.56-29.21$ & 60.37 & $\leq 0.001$ \\
\hline \multirow[t]{2}{*}{ Rhamnus smithi Greene } & 20 & 51.90 & 48.71-55.49 & 28.81 & 0.15 \\
\hline & 40 & 30.55 & $26.00-34.65$ & 64.08 & $\leq 0.001$ \\
\hline \multirow[t]{2}{*}{ Datura alba L. } & 20 & 90.19 & 78.09-110.94 & 59.75 & $\leq 0.001$ \\
\hline & 40 & 86.16 & $69.68-126.09$ & 129.43 & $\leq 0.001$ \\
\hline \multirow[t]{2}{*}{ Periploca aphylla Decne. } & 20 & 79.35 & $65.92-107.27$ & 102.96 & $\leq 0.001$ \\
\hline & 40 & 59.87 & $49.81-77.61$ & 101.16 & $\leq 0.001$ \\
\hline \multirow[t]{2}{*}{ Sonchus asper (L.) Hill } & 20 & 90.51 & 73.84-128.55 & 103.87 & $\leq 0.001$ \\
\hline & 40 & 53.02 & $46.06-62.48$ & 52.03 & $\leq 0.001$ \\
\hline \multirow[t]{2}{*}{ Salvia officinalis L. } & 20 & 38.93 & $34.72-43.14$ & 27.85 & 0.018 \\
\hline & 40 & 17.73 & $8.81-24.14$ & 57.99 & $\leq 0.01$ \\
\hline \multirow[t]{2}{*}{ Dodonaea viscosa (L.) Jacq. } & 20 & 60 & $51.87-72.54$ & 25.22 & 0.028 \\
\hline & 40 & 21.09 & $17.28-24.37$ & 28.22 & 0.016 \\
\hline \multirow[t]{2}{*}{ Olea ferruginea Wall. ex Aitch. } & 20 & 43.17 & $39.21-47.39$ & 25.28 & 0.028 \\
\hline & 40 & 20.05 & $11.69-26.22$ & 44.63 & $\leq 0.001$ \\
\hline
\end{tabular}




\section{Discussion}

This study determined the bioactivity of acetonic extracts of 40 indigenous plant species of Soon valley and surrounding Salt Range of Pakistan against D. citri and A. gossypii. Among all 40 botanical extracts, overall the extracts of $M$. longifolia, M. officinalis and N. indicum and extracts of S. officinalis, D. viscosa and O. ferruginea proved to be most toxic against $D$. citri and $A$. gossypii, respectively, exhibiting minimum $\mathrm{LC}_{50}$ and $\mathrm{LT}_{50}$ values. The observed mortality of citrus psyllid by M. longifolia, M. officinalis and N. indicum would be due to diverse terpenoids and phenolic compounds present in these plant extracts [11-13]. In our study, M. longifolia exhibited about $90 \%$ mortality of D. citri and 58\% mortality of A. gossypii. The extracts of this plant species have been demonstrated to constitute of such bioactive compounds as flavonoids, phenol, saponins, tannin and terpenoids $[14,15]$ that might be responsible for the observed psyllid and aphid mortality in this study. Similarly, D. alba, S. officinalis and N. indicuum extracts is reported to have chemicals such as flavonoids, phenol, saponins, tannin and terpenoids that might be responsible for significant psyllid mortality recorded in this study [15-18]. Similarly, D. viscosa and O. ferruginea plant extracts constitute such phytochemicals as lupeol, stimgasterols, diterpenoids, flavonol-3-methyl ethers and certain fatty acids which have been demonstrated to show bioactivity against different insect pests including lepidopterous[19-20], coleopterous [21] and homopterous pests [22].

\section{Conclusions}

In brief, the extracts of M. longifolia, M. officinalis, N. indicum, D. alba and S. officinalis are found relatively toxic to D. citri, while the extracts of S. officinalis, D. viscosa, O. ferruginea and $M$. longifolia appeared effective against $A$. gossypii, suggesting their incorporation in future integrated pest management for sucking insect pests. Moreover, the biochemical characterization of these plant extracts in order to find out their bioactive constituents responsible for the observed psyllid and aphid mortality and the laboratory and field evaluation of these plant extracts against natural enemies (insect predators and parasitoids) constitute important future perspective of this research work.

Funding: This research work was financially supported by a research project (No. 6702) funded by the Higher Education Commission (HEC) of Pakistan under its National Research Programme for Universities (NRPU).

Institutional Review Board Statement: Not applicable.

Conflicts of Interest: The authors declare no conflict of interest.

\section{References}

1. Ashfaq, S.; Khan, I.A.; Saeed, M.; Saljoqi, A.U.R.; Manzoor, F., Sohail, K., Sadozai, A. Population dynamics of insect pests of cotton and their natural enemies. SJA 201127 2, 251-253.

2. Mahmood, R.; Rehman, A.; Ahmad, M. Prospects of biological control of citrus insect pests in Pakistan. Pakistan J Agri. Res 201452 2, 229-244.

3. Deng, F.; Sun, J.; Dou, R.; Yu, X.; Wei, Z.; Yang, C.; Zhu, L. Contamination of pyrethroids in agricultural soils from the Yangtze River Delta, China. Sci. Total Environ 2020 731, 139-181.

4. Tiwari, S.; Mann, R.S.; Rogers, M.E.; Stelinski, L.L. Insecticide resistance in field populations of Asian citrus psyllid in Florida. Pest Manage Sci 201167 10, 1258-1268.

5. Naeem, A.; Freed, S.; Jin, F.L.; Akmal, M.; Mehmood, M. Monitoring of insecticide resistance in Diaphoria citri Kuwayama (Hemiptera: Psyllidae) from citrus groves of Punjab, Pakistan. Crop Protec 2016 86, 62-68. 
6. Desneux, N.; Decourtye, A.; Delpuech, J.M. The sublethal effects of pesticides on beneficial arthropods. Annu Rev Entomol $200752,81-106$.

7. Haddi, K.; Turchen, L.M.; Viteri Jumbo, L.O.; Guedes, R.N.; Pereira, E.J.; Aguiar, R.W.; Oliveira, E.E. Rethinking biorational insecticides for pest management: unintended effects and consequences. Pest Manage Sci 2020 76 7, $2286-2293$.

8. Kim, S.I.; Roh, J.Y.; Kim, D.H.; Lee, H.S.; Ahn, Y.J. Insecticidal activities of aromatic plant extracts and essential oils against Sitophilus oryzae and Callosobruchus chinensis. J. Stored Prod. Res 2003 39 3, 293-303.

9. Isman, M.B. Botanical insecticides, deterrents, and repellents in modern agriculture and an increasingly regulated world. Annu. Rev. Entomol 2006 51, 45-66.

10. Abbot, W.S. A method of computing the effectiveness of an insecticide. J. Econ. Entomol 192518 2, $265-267$.

11. Odeyemi, O.O.; Masika, P.; Afolayan, A.J. Insecticidal activities of essential oil from the leaves of Mentha longifolia L. against Sitophilus zeamais (Motschulsky) (Coleoptera: Curculionidae). Afr Entomol 2008 16 2, 220-225.

12. EL-Kamali, H.H. Effect of certain medicinal plants extracts against storage pest, Tribolium castaneum Herbst. AEJSA 20093 2, 139-142.

13. Hussain, J.; Muhammad, Z.; Ullah, R.; Khan, F.U.; Khan, I.U.; Khan, N.; Jan, S. Evaluation of the chemical composition of Sonchus eruca and Sonchus asper. Am. J. Sci 20106 9, 231-235.

14. Lee, S.E.; Lee, B.H.; Choi, W.S.; Park, B.S.; Kim, J.G.; Campbell, B.C. Fumigant toxicity of volatile natural products from Korean spices and medicinal plants towards the rice weevil, Sitophilus oryzae (L). Pest Manage Sci 2001 57 6, $548-553$.

15. Govindappa, M.; Poojashri, M.N. Antimicrobial, antioxidant and in vitro anti-inflammatory activity of ethanol extract and active phytochemical screening of Wedelia trilobata (L.) Hitchc. J. Pharmacogn Phytotherapy 2011 3 3, 43-51.

16. Bhuvaneshwari, L.; Arthy, E.; Anitha, C.; Dhanabalan, K.; Meena, M. Phytochemical analysis and antibacterial activity of Nerium oleander. Anc. Sci. Life 200726 4, 24-29.

17. Tomczyk, A.; Suszko, M. The role of phenols in the influence of herbal extracts from Salvia officinalis L. and Matricaria chamomilla L. on two-spotted spider mite Tetranychus urticae Koch. Biol. Lett 201148 2, 193-205.

18. Uddin, G.; Rauf, A.; Akhtar, S. Studies on chemical constituents, phytochemical profile and pharmacological action of $D a-$ tura alba. MEJMPR 2012 11, 14-18.

19. Malarvannan, S.; Giridharan, R.; Sekar, S.; Prabavathy, V.R.; Nair, S. Ovicidal activity of crude extracts of few traditional plants against Helicoverpa armigera (Hubner) (Noctuidae: Lepidoptera). J. Biopestic 20092 1, 64-71.

20. Mohammed, A.K.; Nawar, M.H. Study of the effect of alcoholic extract of Dodonaea viscosa. leaves on the life performance of the greater wax worm Galleria mellonella L. (lepidoptera: pyralidae). Plant Arc 2020 20, 3449-3454.

21. Dimetry, N.Z.; El-Gengaihi, S.; Hafez, M.; Abbass, M.H. Pesticidal activity of certain plant extracts and their isolates against the cowpea beetle Callosobruchus maculatus (F.) (Coleoptera: Chrysomelidae: Bruchinae). Herba Pol 2015 61 3, 77-92.

22. Díaz, M.; Díaz, C.E.; Álvarez, R.G.; González, A.; Castillo, L.; González-Coloma, A.; Rossini, C. Differential anti-insect activity of natural products isolated from Dodonaea viscosa Jacq. (Sapindaceae). J Plant Prot Res 201555 2, 172-178. 